\title{
La Orquesta Sinfónica de Radiotelevisión Española: creación y primeros pasos
}

\author{
The Spanish Radio and Television Symphony \\ Orchestra: Creation and Initial Steps
}

La Orquesta Sinfónica de Radio Televisión Española, una de las más jóvenes de la radio y televisión europeas, se creó en 1964, en plena campaña de los XXV Años de Paz, con la que la dictadura franquista conmemoró su victoria en la Guerra Civil. Asumiendo una actitud de "mecenazgo artístico", el régimen explotó la idea de que España vivía una etapa de desarrollo cultural y musical sin precedentes gracias, sobre todo, a la implicación del Estado. Con independencia de las razones de legitimación política subyacentes, lo cierto es que la creación del nuevo conjunto sinfónico, por iniciativa del Ministerio de Información y Turismo, supuso un hito en la vida musical española. Mediante el análisis de fuentes archivísticas hasta ahora desconocidas, el presente artículo estudia los orígenes de esta orquesta, con especial atención a los condicionantes que determinaron su estructura y primeros conciertos.

Palabras clave: orquestas, radio y televisión, música, franquismo, España, siglo XX.

The Spanish Radio and Television Symphony Orchestra, one of the most recent European orchestras of its kind, was created in 1964, during the campaign known as XXV Años de Paz commemorating the twenty-five anniversary of Franco's victory in the Spanish Civil War. Taking on an attitude of "artistic patronage", the Francoist regime exploited the idea that Spain was experiencing a period of unprecedented cultural and musical development, which was due, above all, to the implication of the State. Regardless of the underlying reasons of political legitimacy, the creation of the new symphonic ensemble, at the initiative of the Ministry of Information and Tourism, became a landmark in Spanish musical life. By analyzing previously unknown archival sources, this article examines the origins of the orchestra, paying particular attention to the factors that determined its structure and early concerts.

Keywords: orchestras, radio and television, music, Francoism, Spain; 20th century.

\section{Introducción}

Durante el franquismo se produjo un reparto en materia de cultura y música que fue fruto, por un lado, de la heterogeneidad política y del equilibrio de poderes entre las distintas familias del régimen - principalmente católicos, falangistas y tecnócratas- y, por otro, de los cambios estructurales que la dictadura hubo de acometer para adaptarse al cambiante contexto 
nacional e internacional ${ }^{1}$. Además, el perfil caudillista que definió a la más alta magistratura del Estado se transmitió a toda la Administración, de manera que la línea de acción de los ministerios cambiaba casi por completo dependiendo de quién se hallara al frente de cada cartera, lo que dio lugar a estrategias dispares, falta de continuidad temporal de los proyectos y políticas contradictorias ${ }^{2}$. En este sentido, el aparato musical del Estado franquista actuó a menudo desde la improvisación y se caracterizó por el continuo traslado de competencias de unos organismos a otros, la multiplicación de nombres e instancias y la permanente mutación tanto de las denominaciones de los departamentos como de las élites que los dirigían. Puede afirmarse, en definitiva, que la dictadura de Franco careció de una política unívoca en los ámbitos cultural y musical; al contrario, tuvo varias, superpuestas y poco duraderas ${ }^{3}$.

Hasta los años sesenta, la política musical del régimen estuvo definida por lo que Pérez Zalduondo llama "concepto elitista de la cultura": la música especializada o culta quedó vinculada a organismos con escasos medios para su promoción -como la Comisaría de la Música, dependiente del Ministerio de Educación-, dado el reducido interés social y político de aquella; en cambio, las manifestaciones musicales de carácter popular fueron confiadas a departamentos con una mejor dotación económica -caso de la Dirección General de Información del Ministerio de Información y Turismo (MIT), o de Sección Femenina, dependiente de la Secretaría General

${ }^{1}$ Jordi Gracia, Miguel Ángel Ruiz Carnicer: La España de Franco (1939-1975). Cultura y vida cotidiana, Madrid, Síntesis, 2001, p. 127. A finales de los años cincuenta, el modelo económico de inspiración fascista que aún perduraba en España produjo una crisis económica de grandes dimensiones. Estas tensiones también se extrapolaron a la sociedad, donde una nueva oposición, alejada del exilio republicano, emergía de la mano de jóvenes estudiantes de izquierdas e intelectuales distanciados de los postulados franquistas. El régimen mutó en 1957 para hacer frente a estos retos económicos y sociales. Los tecnócratas -hombres de negocios, profesionales y técnicos formados en la universidad y relacionados con el Opus Dei- entraron en el Gobierno y pusieron en marcha un programa que combinaba reformas en la Administración Pública y medidas de liberalización económica. La década de 1960 supuso para España un crecimiento económico sin precedentes y el inicio de una tímida apertura puesta de manifiesto en la relajación de la censura tras la promulgación de la Ley de Prensa e Imprenta de 1966. Un período que trajo consigo cambios económicos y sociales que tendrían, además, un importante impacto en la desasistida vida cultural española. Véase al respecto Álvaro Soto Carmona: ¿Atado y bien atado? Institucionalización y crisis del franquismo, Madrid, Biblioteca Nueva, 2005; Pablo Hispán Iglesias de Ussel: La politica en el régimen de Franco entre 1957 y 1969. Proyectos, conflictos y luchas por el poder, Madrid, Centro de Estudios Políticos y Constitucionales, 2006; Nigel Townson: España en cambio: el segundo franquismo (1959-1975), Madrid, Siglo XXI, 2009; Miguel Ángel Giménez Martínez: El Estado franquista. Fundamentos ideológicos, bases legales y sistema institucional, Madrid, Centro de Estudios Políticos y Constitucionales, 2014.

2 Tomás Marco asegura que en lo que se refiere al aspecto musical, "más que la responsabilidad de un Estado que se limitó a inhibirse, hay que hablar de responsabilidad de personas concretas que tienen nombres y apellidos". Historia de la música española. 6. Siglo XX, Madrid, Alianza, 1982, p. 165.

3 Javier Tusell: Dictadura franquista y democracia, Barcelona, Crítica, 2010, p. 104. 
del Movimiento-, con más recursos para su propaganda pero, al mismo tiempo, con mayor tendencia a la censura ${ }^{4}$.

La desventaja de la música clásica empezó a cambiar con la llegada de Manuel Fraga Iribarne al MIT, en 1962. A partir de esa fecha, el Ministerio asumió una actitud aperturista que podríamos denominar de "convocatoria intelectual", un intento de atraer a intelectuales y artistas para conseguir así la "modernización” y "actualización" que España precisaba Aunque esta actitud aperturista tendría más impacto en la forma que en el fondo, comportó, no obstante, una clara promoción de las corrientes artísticas minoritarias, sin las que difícilmente se entiende el auge de la música clásica a lo largo de la década de los sesenta ${ }^{6}$. En este proceso de apertura jugaron un papel decisivo una serie de jóvenes políticos que Moreno Galván ha agrupado bajo la etiqueta de "generación Fraga" . En realidad, no se puede analizar la labor del ministro sin profundizar en la gestión de quienes ocuparon los puestos clave de la política artística y musical dentro del Ministerio, y, en concreto, de la Dirección General de Información, que

\footnotetext{
${ }^{4}$ Gemma Pérez Zalduondo: "Que nada aparezca en la calle que resulte ajeno a los intereses del Estado'. La música en el Ministerio de Información y Turismo (1951-1956)", Music and Francoism, Gemma Pérez Zalduondo y Germán Gan Quesada (coords.), Turnhout, Brepols, 2013, p. 201.

${ }^{5}$ Hay que señalar que esta apertura cultural había estado precedida por otras antes, que ya tuvieron su impacto en el desarrollo y promoción de ciertas manifestaciones artísticas durante los años cincuenta, algunas de ellas relacionadas con la vanguardia pictórica o escultórica. Con la exhibición de aquella "normalidad cultural", el régimen había encontrado un argumento propagandístico para encubrir su carácter autoritario en lo político (Juan Manuel Bonet: "De una vanguardia bajo el franquismo", Arte del franquismo, Madrid, Cátedra, 1981, p. 206). En este sentido, el primer gran espaldarazo oficial al arte de vanguardia llegó con la celebración de la I Bienal de Arte Hispanoamericana, en 1951, llevada a cabo por el Instituto de Cultura Hispánica (ICH). En este acontecimiento tuvo ya un papel relevante Fraga, dado que, por aquel entonces, era secretario general del ICH. Junto a él, Alfredo Sánchez Bella (presidente del ICH), Leopoldo Panero (secretario general de la Bienal), Joaquín Ruiz-Giménez (presidente del Consejo Asesor en su calidad de ministro de Educación) y Pedro Laín Entralgo (miembro del Claustro). Véase Miguel Cabañas Bravo: La política artística del franquismo, Madrid, CSIC, 1996, pp. 157 y ss.

${ }^{6}$ Son varios los autores que coinciden en señalar el cambio de tendencia en la política musical del franquismo con el nombramiento de Fraga como ministro de Información y Turismo. Tomás Marco habla de "raquitismo" en las instituciones musicales hasta 1962. La música de la España contemporánea, Madrid, Publicaciones Españolas, 1970, p. 37. Llorenç Barber, por su parte, señala que la nueva música, en un principio apoyada por Ateneos, Juventudes Musicales y el Instituto Alemán, será promocionada en los años sesenta "por la ruda maquinaria 'cultural' fraguista". "Notas sobre la post-modernidad española", 14 compositores españoles de hoy, Emilio Casares (coord.), Gijón, Universidad de Oviedo, 1982, p. 45. Ángel Medina apunta un espectacular salto cuantitativo en el panorama musical español debido al mecenazgo oficial, en el que tuvo mucho que ver "el nervioso" ministro. "Primeras oleadas vanguardistas en el área de Madrid", Actas del Congreso Internacional "España en la música de Occidente”, Emilio Casares, Ismael Fernández de la Cuesta y José López-Calo (eds.), vol. 2, Madrid, Ministerio de Cultura-Instituto Nacional de las Artes Escénicas y de la Música, 1987, p. 381.

7 Juan Triguero (pseudónimo de José María Moreno Galván): "La generación de Fraga y su destino", Cuadernos de Ruedo Ibérico, n. ${ }^{\circ}$ 1, junio-julio de 1965, pp. 5-16. Entre ellos destacaron Carlos Robles Piquer en la Dirección General de Información, Roque Pro Alonso en la de Radiodifusión y Televisión, José María Escudero en la de Cinematografía y Teatro, Manuel Jiménez Quílez en la de Prensa, y Pío Cabanillas, subsecretario del Ministerio. Esta generación política nutrió las filas de la Administración y formó parte del proceso de modernización de España durante estos años.
} 
tenía responsabilidad sobre asuntos de índole cultural.Al frente de esta Dirección General, Carlos Robles Piquer $^{8}$ se ocuparía, "con mentalidad abierta", de la cultura popular, que abarcaba "todo lo imaginable -libros, conciertos, Festivales de España-" estaba dividida, a su vez, en tres departamentos. Uno de ellos, la Subdirección General de Cultura Popular, promovía y realizaba actividades de carácter musical particularmente dirigidas al gran público. Pero esta Subdirección asumió no solo la organización de eventos generalistas, sino también lo relacionado con la música culta, al quedar incorporada esta a la política de ocio y educación popular del Ministerio ${ }^{10}$. Robles Piquer nombró responsable de este departamento a Enrique de la Hoz Díaz, quien con el tiempo llegaría a convertirse en "uno de los protagonistas de la política musical y artística española" 11.

Nada más hacerse cargo de sus responsabilidades, Enrique de la Hoz redactó un informe ${ }^{12}$ en el que constataba que "el manejo y proyección de la música 'viva' en España”, labor tradicionalmente asociada al Ministerio de Educación y su Dirección General de Bellas Artes, había quedado reducida a una cosa "mínima y enteca". La abulia de la actividad musical oficial estaba lastrada, además, por el "pésimo entendimiento" que tradicionalmente había existido entre el Ministerio de Educación y su Comisaría de la Música, donde predominaba el elemento católico, y el MIT, controlado por los falangistas. A todo lo cual había que añadir la "catastrófica política musical empleada en la Radio -en la oficial también- y en la Televisión, que son punto y aparte". Para romper con esta dinámica, De la Hoz planteaba como objetivo prioritario intensificar la promoción de conciertos y eventos musicales con la ayuda de todos los departamentos ministeriales:

\footnotetext{
8 "Más a título de cuñado que por procedencia política", según Gabriel Elorriaga: El camino de la concordia. De la cárcel al Parlamento, Barcelona, Debate, 2008, p. 102.

${ }_{9} \mathrm{Ibid}$. En esta tarea artístico-musical tendría también un papel destacado la Dirección General de Radiodifusión y Televisión, conducida desde 1964 por Jesús Aparicio-Bernal, que sirvió de escaparate a algunas de las actividades organizadas por la Dirección General de Información tanto dentro como fuera del país.

${ }^{10}$ Una de sus empresas más destacadas, que incluía música culta y popular, era la organización de la Red Nacional de Festivales de España.

${ }^{11}$ Sin duda, el mayor reconocimiento a la figura de Enrique de la Hoz lo encontramos en el obituario que escribió Carlos Robles Piquer ("Adiós a Enrique de la Hoz", ABC, 14-VIII-1996, p. 71) con motivo de su fallecimiento: "A [Enrique de la Hoz], primer artífice del desarrollo de los Festivales de España, [...] le corresponde también la idea inicial de crear la Orquesta Sinfónica de RTVE, [... y y también fue idea suya la de lanzar el gran espectáculo [... la la 'Antología de la Zarzuela".

12 Aunque fue elaborado en octubre de 1962, aparece incluido en el dosier redactado con motivo de la creación de la Orquesta de Radiotelevisión Española en 1965. "Notas sobre la creación de una orquesta titular del Ministerio de Información y Turismo", Archivo General de la Administración (AGA), Fondo (3) 49.09, Legajo: 38674, Sig. Top. 23/54.
} 
Música en primer grado y abundantemente tendrán los Festivales de España, las campañas de Cultura Popular, la permanente "alimentación" musical a los Colegios Mayores, Ateneos, Centros Culturales de toda España, Sociedades Filarmónicas, etc. Será absolutamente necesaria, pues, la más efectiva, cordial, verdadera, intensa, común y sincera colaboración que tiene que prestar a esta amplia, diversa e importante inquietud musical promovida y "movida" por el Ministerio de Información, la Comisaría de la Música y los Organismos Oficiales de directa preocupación por la cultura musical ${ }^{13}$.

El llamamiento a una cooperación entre los ministerios y organismos oficiales no ocultaba, por otro lado, la intención decidida de Cultura Popular y del MIT de posicionarse como principales impulsores de la actividad musical del país:

Inevitablemente, el Ministerio de Información será, o lo es ya, el Organismo oficial de mayor consumo de música. El consumo, la presencia y la divulgación de la música en Radio Nacional, en TVE, en Festivales de España, en el Ateneo de Madrid, en el resto de actividades ya citadas antes, es infinitamente superior en cifras y amplitud a todo de lo mismo que se haga en otros lugares, oficiales o privados ${ }^{14}$.

Desde ese instante, la música se convertiría en elemento principal de la política cultural del Ministerio, que tuvo especial ocasión de manifestarse en 1964, durante la campaña de los XXV Años de Paz, lema bajo el que la dictadura celebró el $25^{\circ}$ aniversario de su triunfo en la Guerra Civil ${ }^{15}$. El franquismo aprovechó la efemérides para proyectar una imagen más amable de sí mismo tanto dentro como fuera de sus fronteras, fin para el que la música resultó una valiosa herramienta. Se trataba de reforzar la legitimidad de la dictadura aludiendo más al ejercicio y la gestión diarios que a sus orígenes bélicos, por lo que fue de enorme utilidad el uso de un discurso que resaltara los logros en materia cultural.

El Ministerio de Información y Turismo fue el máximo responsable de la organización de los XXV Años de Paz ${ }^{16}$, quedando la Subdirección de

${ }^{13} \mathrm{Ibid}$

${ }^{14} \mathrm{Ibid}$.

15 Paloma Aguilar considera los XXV Años de Paz "la mayor campaña propagandística del régimen en toda su historia", en Políticas de la memoria y memorias de la política. El caso español en perspectiva comparada, Madrid, Alianza, 2008, p. 189. Cuidadosamente orquestada desde el poder, la operación fue deudora de los fastos fascistas que ritualizaban y sacralizaban la política. Su principal objetivo no fue otro que la justificación de la continuidad de la dictadura. Para ello, el régimen orientó todo su discurso hacia los logros y el desarrollo experimentados durante los últimos veinticinco años, especialmente en el ámbito económico, pero también en lo social y artístico.

${ }^{16}$ La Junta Interministerial encargada de llevar a cabo tan importante celebración estaba dirigida por tres miembros del MIT: Manuel Fraga, que actuó como presidente; Pío Cabanillas, como vicepresidente; y Carlos Robles Piquer, como secretario y comisario de la conmemoración. "Decreto 2531/1963, por el que se crea una Junta Interministerial para preparar la conmemoración del XXV aniversario de la Paz Española", Boletín Oficial del Estado (BOE), n. ${ }^{\circ} 248,16-X-1963$. 
Cultura Popular a cargo de las manifestaciones musicales ligadas a la conmemoración: los revigorizados Festivales de España, el Concierto de la Paz -que impulsó la política de encargos a compositores españoles y la promoción de la vanguardia musical ${ }^{17}$ - y el I Festival de Opera de Madrid, género largamente desatendido en la capital ${ }^{18}$. Aunque hubo otras actividades musicales oficiales que no participaron explícitamente del aniversario -como el I Festival de Música de América y España ${ }^{19}$ o la I Bienal de Música Contemporánea-, todas ellas quedaron indefectiblemente invadidas por el discurso conmemorativo ${ }^{20}$.

\section{Creación de la Orquesta Sinfónica de RTVE}

No es de extrañar, por tanto, que la creación de la Orquesta Sinfónica de Radiotelevisión Española (OSRTVE) se produjera precisamente en 1964, culminando un año especialmente intenso en el ámbito sinfónico ${ }^{21}$. Una nueva orquesta con la que se remataba una trayectoria iniciada hacía veinticinco años, ya que a juicio de Enrique de la Hoz fue entonces -y no antes- cuando el Estado, “con una consciente sensibilidad", asumió el papel de "mecenas para la cultura":

${ }^{17}$ El Concierto de la Paz se celebró en Madrid el 16 de junio de 1964 y puede considerarse el primer espaldarazo oficial a la música española de vanguardia. En el concierto se dieron cita obras de Cristóbal Halffter, Luis de Pablo, Ángel Arteaga y Miguel Alonso. Un análisis profundo de este evento ha sido realizado por Igor Contreras Zubillaga: "El Concierto de la Paz: tres encargos estatales para celebrar el 25 aniversario del franquismo", Seminario de Historia, Universidad Complutense de Madrid, 2011, https://www.ucm.es/data/cont/docs/297-2013-07-29-2-11.pdf (última consulta: 15-10-2016).

18 Desde el cierre del Teatro Real, en 1925, Madrid había carecido de una temporada regular de ópera. La primera edición de este festival tuvo lugar entre el 10 de mayo y el 11 de junio de 1964.

${ }^{19}$ Para una aproximación a este evento y a sus consecuencias musicales, sociales y políticas, véase Daniel Moro Vallina: "El Festival de Música de América y España (1964-1970). Intercambios musicales entre las dos orillas", Cuadernos de Música Iberoamericana, vol. 24, Madrid, ICCMU, 2012, pp. 143-173.

${ }^{20}$ En este sentido, Ángel Medina: "Primeras oleadas vanguardistas en el área de Madrid", Actas del Congreso Internacional..., p. 381, habla de la "eclosión musical de 1964". Un hecho que resulta sorprendente, "habida cuenta -sostiene Emilio Casares- del mínimo interés que el arte del sonido despertó en el general Franco y en todos los Gobiernos de que se rodeó". E. Casares: Cristóbal Halffter, Gijón, Universidad de Oviedo, 1980, p. 107. No obstante, tal y como se verá más adelante, la música ocuparía un lugar destacado en la política del Ministerio de Información y Turismo durante el mandato de Fraga. Es cierto que anteriores ministros dieron muestras de cierta afición musical, caso de los titulares de Educación José Ibáñez Martín (1939-1951) y Jesús Rubio García-Mina (1956-1962). Sin embargo, este hecho no sirvió para dotar a la Comisaría de la Música de un presupuesto que ayudase a desempeñar una política musical relevante en aquellos años: "Ni aun la presencia de un ministro de filarmonía y devoción musical tan probada como Jesús Rubio [...] pudo servir para que por Hacienda, dentro de los presupuestos generales del país, se dotase a la música de unos medios económicos dignos". Véase Antonio Fernández-Cid: La música española en el siglo XX, Madrid, Fundación Juan March, 1973 , p. 340.

${ }^{21}$ Hay que señalar que en poco más de un año se crearon tres nuevas orquestas adscritas a diferentes organismos oficiales: la Orquesta Universitaria del Sindicato Español Universitario (SEU) -en marzo de 1964, bajo la dirección de Luis Antonio García Navarro ("Presentación de la Orquesta Nacional Universitaria", El Alcázar, 10-III-1964, p. 28)-, la Orquesta de Cuerda del Aula de Música del Servicio 
Así fue posible que naciera la primera orquesta oficial del Estado Español, la Orquesta Nacional. Y así ha sido posible que, cuando la Nacional -la hermana mayor- es ya un fruto sazonado, logrado a la medida de los moldes exigentes que tiene la gran música universal, así ha sido posible que nazca también la Orquesta Sinfónica de la RTV Española ${ }^{22}$.

La idea de crear una nueva orquesta vinculada a la radio y la televisión públicas no era nueva. Hacía años que la manejaban los responsables de la Dirección General de Información, del mismo modo que se había convertido en una demanda generalizada entre los profesionales de la música ${ }^{23}$. Así, ya en un recorte de prensa de noviembre de 1962 -de autor desconocido- se reconocía abiertamente que la Orquesta Nacional de España (ONE) era insuficiente para hacer frente a una política musical "nacional" y completa:

Hacen falta un par de orquestas más, en idéntica o parecida dimensión, en idéntica o parecida calidad. La televisión española, cuando el capítulo de la publicidad se agranda afortunadamente, podría ir a esta empresa nacional: su gran orquesta. [...] No basta con la Orquesta Nacional. El monopolio es también aquí un impedimento para los esclarecimientos y el proselitismo, sobre que esta reciente y afortunada experiencia fuerza a hablar de la necesidad de la competencia como medida de agitación. Nunca serán perniciosas estas filiaciones pasionales, aunque alcancen dimensiones wagnerianas.Aquí, en música, como en otras muchas cosas, lo peor es la atonía 24 .

Lo cierto es que España se encontraba en clara desventaja, al ser el único país de su entorno que no contaba con una orquesta adscrita a la actividad de la radio y la televisión estatales ${ }^{25}$. No obstante, esto no siempre había sido

Nacional de Educación y Cultura del Movimiento -en octubre de 1964, dirigida por Benito Lauret (Federico Sopeña: "Nueva orquesta en 'Aula de Música", ABC, 13-X-1964, p. 86)- y la que nos ocupa.

22 "Palabras del subdirector general de Cultura Popular en el homenaje a la memoria de Ataúlfo Argenta en Castro Urdiales. Por la Orquesta Sinfónica de la RTV Española”, 22-VIII-1965, p. 2, AGA, Fondo (3) 49.12, Legajo: 44201, Sig. Top. 23/72.

${ }^{23}$ Para Federico Sopeña era "absurdo que la radio y la televisión no cuenten con una orquesta permanente [...]. Evitaríamos así la improvisación, el que una orquesta llegue a un concierto como el de la otra noche a cumplir un menester pasajero y no con un director con el que trabaja todos los días". "Teresa Berganza", ABC, 28-XII-1960, p. 96.

24 "España: pasión por la música", AGA, Fondo (3) 49.09, Legajo: 38664, Sig. Top. 23/54. Este artículo, encontrado entre los documentos de la Subdirección de Cultura Popular, aparece subrayado y adjunta una pequeña nota donde se lee "Sr. De la Hoz", escrita a mano, y a continuación "Hablarme de este tema", a máquina. Posiblemente el artículo fuese dirigido a Enrique de la Hoz por alguno de sus superiores, Robles Piquer o Fraga, preocupados por la reacción de la prensa ante los nuevos acontecimientos musicales e interesados en crear una orquesta al calor de la radio y televisión públicas. En una línea similar, Juana Espinós Orlando apuntaba diversas medidas para intensificar la vida musical española, como "Abrir las puertas del Teatro Real, sostener una temporada permanente de teatro lítico en la Zarzuela [...], crear las orquestas de la Radio y la Televisión", J. Espinós: "Glosa Musical a 'Corto y Ceñido"', Madrid, 22-XII-1962.

25 Portugal, Francia, Italia, Gran Bretaña, Alemania y Austria, entre otros países europeos, contaban con conjuntos musicales dependientes de los medios de comunicación oficiales. 
así. Desde 1945 había funcionado la Orquesta de Cámara de Radio Nacional, conocida como Orquesta de Cámara de Madrid, cuando Radio Nacional de España (RNE) pertenecía a la Vicesecretaría de Educación Popular del Movimiento. Esta orquesta, que ofrecía hasta tres conciertos semanales, fue impulsada por Ataúlfo Argenta, quien fue además su director y contó con el mecenazgo del marqués de Bolarque y el asesoramiento de Joaquín Rodrigo ${ }^{26}$. En 1948, una vez que RNE pasó a depender del Ministerio de Educación ${ }^{27}$, se organizó una nueva orquesta dirigida por el italiano Napoleone Anovazzi y el español Conrado del Campo. Tras la creación del MIT -y el consiguiente traslado de las competencias en materia de radiodifusión al nuevo Ministerio- se formó, en 1952, otro conjunto orquestal gracias a la iniciativa de Enrique Franco (entonces jefe de Programas Musicales de RNE), dirigido por Ataúlfo Argenta y cuyos miembros pertenecían a la $\mathrm{ONE}^{28}$. Al año siguiente, el entonces ministro de Información y Turismo, Gabriel Arias-Salgado, quiso recortar gastos y suprimió esta orquesta ${ }^{29}$.

Por tanto, hacía más de diez años que la radio pública española carecía de una orquesta titular. Un largo tiempo en el cual, lejos de disminuir, las necesidades de RNE habían aumentado; y a ellas había que sumar ahora las de Televisión Española (TVE), cuyas emisiones comenzaron en 1956. La actividad que en materia musical estaba llevando a cabo la Subdirección de Cultura Popular, a través de los ciclos de conciertos, los Festivales de

\footnotetext{
${ }^{26}$ Véase José Ramón Ripoll: Cuarenta años sonando. La Orquesta Sinfónica de RTVE (1965-2005), Madrid, Radio Televisión Española, 2005, p. 11. Por su parte, Luis de Urquijo y Landecho, marqués de Bolarque, era, además de banquero y diplomático, "musicómano de tiempo completo", como lo calificó Enrique de la Hoz en una nota interna depositada en el AGA, Fondo (3) 49.09, Legajo: 38670 , Sig. Top. 23/54. Así, fue sucesivamente miembro del Consejo Nacional de Música (BOE, n. ${ }^{\circ} 98,8$ IV-1941), director de la Sección de Música del Ateneo de Madrid (BOE, n. $\left.{ }^{\circ} 299,26-X-1950\right)$ y vocal de la Comisión patrocinadora del I Festival de Música de América y España, celebrado en octubre de 1964 ("I Festival de Música de América y España. Comisiones", AGA, Fondo (3) 49.09, Legajo: 38669, Sig. Top. 23/54).

${ }^{27}$ En 1945 se trasladaron todos los organismos sobre prensa y propaganda al Ministerio de Educación Nacional, al mismo tiempo que se privaba de ellos a los falangistas de la Vicesecretaría de Educación Popular (BOE, n. ${ }^{\circ}$ 209, 28-VII-1945). Se transfirieron igualmente las atribuciones que en materia musical les estaban asociadas. Esta decisión, que supuso un duro revés político para Falange, formaba parte del intento del régimen por acomodar su imagen tras la derrota de los fascismos en la Segunda Guerra Mundial.

28 "Entonces la Nacional no tocaba los domingos en el Monumental Cinema ni casi salía de Madrid, lo cual permitió a la Radio disponer de una labor continuada, cosa que actualmente, con la misma fórmula, sería imposible". "Notas sobre la creación de una orquesta titular del Ministerio..., p. 3. A través de esta orquesta empezaron a tomar contacto con la dirección jóvenes maestros españoles como Odón Alonso, Cristóbal Halffter o Francisco Calés Otero.

${ }^{29}$ Lo que provocó un conflicto laboral entre el Ministerio y los profesores de la orquesta, quienes interpusieron una demanda contra la Administración al entender que su contrato se había roto de forma unilateral. Diez años más tarde (BOE, n. ${ }^{\circ}$ 164, 10-VII-1963) se hizo pública la sentencia que ordenaba al Estado a compensar económicamente a los profesores afectados.
} 
España o la creación del Festival de Ópera de Madrid, hacía más perentoria si cabe la creación de una nueva orquesta.

En la primavera de 1964, a propósito de la inauguración del I Festival de Ópera, Carlos Robles Piquer dirigió una nota a Fraga recordándole la "urgente necesidad" de que el Ministerio tuviese su propia orquesta, "independiente", para que pudiese resolver "con total dignidad" situaciones como la planteada a la Orquesta Sinfónica de Madrid durante la representación de Tosca, ópera que había inaugurado el antedicho festival: "Tal Orquesta demostró [...] estar lejos de las exigencias musicales de unas obras como las que integran este festival. El fallo de los violoncelos en el tercer acto creó en el público un clima adverso que impidió finalizar la ópera con el entusiasmo que hubiera sido de desear" ${ }^{\prime 3}$.

Concluía la nota asegurando que la creación de una nueva orquesta era completamente necesaria, "no ya para la vida musical española, sino simplemente para la madrileña”. Así, poco después se publicó la orden ministerial que autorizaba a la Dirección General de Radiodifusión y Televisión a crear una orquesta sinfónica ${ }^{31}$. Se materializaba así uno de los proyectos culturales más ambiciosos del MIT, que venía a cubrir las necesidades de dos de sus Direcciones Generales: Información y Radiodifusión y Televisión. La iniciativa, no obstante, había partido de la primera.Así lo reconocía el subdirector de Cultura Popular, Enrique de la Hoz:

La idea chisporroteó en las noches del verano de 1964 en El Escorial [...]. Carlos Robles Piquer y el que esto cuenta [...] le presentaron al ministro responsable de aquellos festejos un plan para montar una orquesta propia. [...] Manuel Fraga Iribarne acogió la idea, que iba bien razonada, con beneplácito.Y dijo que adelante con una condición: la Orquesta se titularía Sinfónica de la Radiotelevisión Española puesto que podía ser pagada por los ingresos procedentes de la publicidad televisiva, descartando que se llamara de Festivales de España, ya que estos eran pobres para afrontar una nómina de tanto calado económico como se proyectaba $^{32}$.

\footnotetext{
30 Nota de Carlos Robles Piquer a Manuel Fraga, 11-V-1964, AGA, Fondo (3) 49.09, Legajo: 38669, Sig. Top. 23/54. Este fiasco también apareció reflejado en la prensa. Así, en la crónica de Serafín Adame se leía: "En el amanecer de Tosca no concluía de salir el sol [...] ¡ni el Re o cualquier otra nota de Puccini!". "La ópera de Madrid combate la falta de puntualidad del público", Pueblo, 18-V1964 , p. 16.

${ }^{31}$ Orden de 18 de junio de 1964 por la que se crea la Orquesta de la Radio y Televisión, BOE, n. ${ }^{\circ}$ 155, 29-VI-1964.

32 Enrique De la Hoz: "1965-1995: Una sinfonía de 30 años. La creación de la Orquesta de RTVE”, Veintiuno, n. ${ }^{\circ} 28$, enero de 1996, p. 121. Una versión similar ofrece Carlos Robles Piquer: "Recuerdo cuando Enrique y yo fuimos a proponer al ministro la creación de una orquesta sinfónica y coro como alternativa a la Orquesta Nacional del Ministerio de Educación Nacional. Fraga, buen melómano, aceptó en seguida la idea y vio en RTVE al organismo que podría pagarla y constituir su principal 'cliente'. Así ocurrió, pero la nueva orquesta fue también una valiosa protagonista en los Festivales”, Memoria de cuatro Españas..., p. 187. Manuel Fraga Iribarne retrasa la decisión de crear la nueva orquesta a diciembre
} 
La materialización de este proyecto demandaba el consejo y la implicación del Ministerio de Educación. Algo que parecía lógico si se tiene en cuenta que este departamento contaba con la probada experiencia de la ONE y, al mismo tiempo, había que delimitar las respectivas esferas de actuación para que la nueva orquesta no perjudicara a la ya existente. Con este objetivo se convocaron varias reuniones en las que estuvieron presentes los ministros y subsecretarios de ambos Ministerios: Manuel Fraga y Pío Cabanillas, por parte del MIT; Manuel Lora Tamayo y Luis Legaz Lacambra, por el de Educación. A ellos se sumó el grupo directivo de la Orquesta Nacional -Gratiniano Nieto (director general de Bellas Artes), Antonio de las Heras (secretario técnico de la Música) y Rafael Frühbeck de Burgos (director de la ONE) - y los que tendrían responsabilidad directa sobre la nueva orquesta -Carlos Robles Piquer (director general de Información), Jesús Aparicio-Bernal (director general de Radiodifusión), Enrique de la Hoz (subdirector de Cultura Popular) y Cristóbal Halffter (director del Conservatorio de Música de Madrid y uno de los primeros directores del conjunto sinfónico). También asistieron, en calidad de invitados, los críticos Federico Sopeña y Enrique Franco ${ }^{33}$. Tras la primera toma de contacto se decidió crear un grupo de trabajo más selecto, una "Comisión de carácter técnico" integrada por De las Heras, Frühbeck, De la Hoz y Halffter, quienes pueden ser considerados los "fundadores-fundadores" 34 de la Orquesta.

El nacimiento del nuevo conjunto iba a suponer un salto cualitativo en la política musical desarrollada por el MIT y "una auténtica extensión popular de la música culta", como subrayaba el informe realizado por Cultura Popular y elaborado al calor de las citadas reuniones ${ }^{35}$. La creación de la OSRTVE significaba disponer, al fin, de un organismo estable con el que cubrir la mayor parte de conciertos de la Red de Festivales de España, aparte de otros espectáculos de ópera y ballet y eventos musicales como los "conciertos-homenaje a ilustres músicos", o los ciclos de Semana Santa y Navidad, que podrían prescindir de la "música alquilada". Del mismo modo, el Ministerio pensaba fomentar los conciertos en provincias fuera de la temporada de Festivales, entre octubre y mayo, con la

de 1963, durante una cena con personalidades del mundo musical español: "Se toma una decisión muy importante: la creación de la Orquesta de Radio y Televisión, decisiva en la promoción de la música sinfónica". Memoria breve de una vida pública, Barcelona, Planeta, 1980, p. 95. Por su parte, Cristóbal Halffter habla de una cena con Fraga para tratar asuntos de la orquesta recién creada en diciembre de 1964 ("Situación crítica del compositor en España", ABC, 6-IV-1968, p. 23); quizá se trate de la misma velada que refiere el ministro en sus memorias y que sitúa en 1963.

33 Enrique De la Hoz: "1965-1995: Una sinfonía de 30 años...", p. 122.

${ }^{34} \mathrm{Ibid}$.

35 "Notas sobre la creación de una orquesta titular del Ministerio...", p. 1. 
colaboración de Sociedades Filarmónicas, Ateneos y Universidades. Con ello se perseguía la "extensión" y la "descentralización" de la acción musical oficial ${ }^{36}$.

Como es lógico, la Orquesta de Radiotelevisión debía tener una presencia destacada en los medios de comunicación públicos. Entre las intenciones de los responsables estaba la de establecer, al menos, un programa musical a la semana en $\mathrm{TVE}^{37}$ y un buen número en RNE. Es precisamente en la radio donde la orquesta debería tener un papel más relevante, como portavoz de la joven creación musical española. De esta forma, se revertiría la tendencia de los últimos diez años en Radio Nacional, donde apenas se había dado a conocer nada de "lo que se escribe, se compone y circula en el campo universal de la música contemporánea": "Los compositores nacionales estrenarían en España y no en los Festivales europeos, como viene sucediendo con los más notables, por ejemplo, Cristóbal Halffter o Luis de Pablo. La orquesta del Ministerio en la Radio daría a conocer un repertorio que no se interpreta ni por la Orquesta Nacional ni por nadie y se serviría así a una cultura viva" 38 .

Aunque se pensaba que la OSRTVE significaría "un paso más de popularidad y simpatía en la actual etapa política del Ministerio de Información y Turismo" 39 , no pasaban inadvertidos algunos inconvenientes, como la "inexistencia de buenos elementos con que mantener las dos Orquestas del Estado". Al menos ésa era la preocupación del director de la ONE, Rafael Frühbeck, quien además temía que parte de la plantilla de su orquesta solicitase pasarse a la nueva ante la promesa de sueldos comparativamente más altos.Y es que, efectivamente, ése era uno de los reclamos de la Orquesta Sinfónica de RTVE al asegurar un salario "propio de una clase social decorosa y de nivel acomodado": "Un profesor de orquesta tiene una carrera larga (de las más largas), está en trance permanente de estudio y

\footnotetext{
36 "En el presente año se han utilizado diecisiete orquestas de concierto y acompañamiento, generalmente con mal servicio e improvisación constante. Así no se lleva a las provincias buena música". Ibid., pp. 9-10.

${ }^{37}$ Por entonces, TVE ofrecía media hora de retransmisión de música clásica los domingos a mediodía. Sin duda, el tratamiento que daba el ente público a la música sinfónica estaba todavía alejado de las prácticas de otros países europeos: "Cualquier Televisión europea, y especialmente si es del Estado, tiene un porcentaje de programas para la música culta diez veces superior, por lo menos, a la TVE. [...] Un programa diario de música culta es lo que da cualquier televisión de cualquier país culto, sumando de ocho a diez horas a la semana contra una en la TVE". Ibid., p. 3.

${ }^{38}$ Este perfil respondía a la necesidad de diferenciarse de la programación de la Orquesta Nacional: "Ambas deberán realizar funciones complementarias, si bien distintas. [...] La del Ministerio deberá operar con libertad de criterio y acción. Su programa deberá cubrir en gran parte el que no realiza precisamente la Nacional, y muy especialmente deberá servir de puerta franca hacia la joven generación de músicos españoles". En principio, incluso se pretendía crear un conjunto, dentro de la OSRTVE, para la interpretación de música contemporánea. Ibid., pp. 4, 6 y 8.

39 Ibid., p. 1.
} 
ocupa un puesto en la sociedad que exige educación cívica superior, aceptable cultura media y, normalmente, viste de frac" ${ }^{40}$.

Para evitar que se produjese un traslado masivo desde la Orquesta $\mathrm{Na}-$ cional se acordó impedir la entrada en el nuevo conjunto a los mayores de cuarenta y cinco años ${ }^{41}$. De forma paralela se reconocieron ciertas remuneraciones complementarias al sueldo de los profesores de la ONE -que oscilaban de las 24000 a las 48000 pesetas al año por profesor- y se aplicó un aumento salarial en función de los años trabajados ${ }^{42}$. Por último, las Direcciones Generales de Bellas Artes e Información limitaron a trece el número máximo de profesores que podrían solicitar el paso de una orquesta a otra, "cifra reducida y que no impediría el normal desenvolvimiento de las actividades de la Orquesta Nacional"43.

Con estas medidas quería evitarse la proliferación de conflictos entre la OSRTVE y la ONE y, por extensión, entre los responsables de los ministerios implicados. No en vano, la idea de que una segunda orquesta supondría un grave daño para la admirable y ya veterana Orquesta Nacional era común en algunos ambientes musicales madrileños y aparecía recogida en la prensa ${ }^{44}$. Por esa razón, Fraga hubo de esforzarse por convencer a su homólogo, Lora Tamayo, de que se habían tomado "todas las precauciones posibles" para no causar perjuicios a la $\mathrm{ONE}^{45}$. Unas precauciones en las que insistió durante la toma de posesión de los profesores de la

40 Ibid., p. 12. Los sueldos oscilarían, según se indicaba en el "Reglamento de la Orquesta de la Radio y Televisión Española" (AGA, Fondo (3) 49.12, Legajo: 44218, Sig. Top. 23/72), entre las 13000 y las 20000 pesetas mensuales. Una cantidad muy superior a la establecida en otras agrupaciones. Sin ir más lejos, los profesores de la Orquesta Nacional percibían un sueldo medio de unas 4000 pesetas; los de la Banda Municipal, alrededor de 5000; y los de la Banda Militar, 7500 pesetas en el caso de los sargentos y 8300 en el de los brigadas. "Informe sobre la situación de la Orquesta Sinfónica de la RTV Española”, 30-IV-1968, AGA, Fondo (3) 49.12, Legajo: 44218, Sig. Top. 23/72.

${ }^{41}$ Otra de las condiciones era acreditar "buena conducta" mediante la "presentación de los certificados correspondientes de la autoridad municipal y del Registro de Penados y Rebeldes". BOE, n. ${ }^{\circ}$ 173, 20-VII-1964.

42 BOE n. $^{\circ}$ 143, 15-VI-1964. Antonio Fernández-Cid mostraba su satisfacción por este incremento salarial: "Llega a su término de forma dignísima una vieja, legítima, sustancial aspiración de todos los componentes de la Orquesta Nacional". "Nuevas retribuciones a la Orquesta Nacional", Informaciones, 8-IV-1964. Poco antes, en enero de ese mismo año, el crítico había publicado otro artículo, titulado "Orquesta Nacional en peligro", donde precisamente criticaba los bajos sueldos de los profesores de la ONE.

${ }^{43}$ Carta de Manuel Fraga a Manuel Lora Tamayo, 8-I-1965, AGA, Fondo (3) 49.09, Legajo: 38674, Sig. Top. 23/54. Finalmente, solo tres profesores de la Nacional pidieron traslado a la nueva orquesta. Véanse los detalles de este trasvase en la carta de Manuel Fraga a Manuel Lora, 27-I-1965, AGA, Fondo (3) 49.09, Legajo: 38674, Sig. Top. 23/54.

${ }^{44}$ Así lo recogía Federico Sopeña en "Orquesta de la Radio-Televisión”, ABC, 20-IX-1964. Por su parte, Enrique Franco apuntaba: "Es inevitable hablar aquí de la Orquesta Nacional [... ] para alejar desde el principio toda idea de competencia, a la que tan proclive se viene manifestando el gran auditorio musical [...]. No era, pues, competencia lo que se buscaba, sino complemento". Sensacional presentación de la Orquesta Sinfónica de RTV Española, dirigida por Markevitch", Arriba, 28-V-1965, p. 20.

45 Carta de Fraga a Lora Tamayo, 8-I-1965. 
orquesta: "Nuestra Orquesta no viene a anular, ni siquiera a sustituir nada ni a nadie" 46 .

Al final, lo cierto es que la convivencia de las dos orquestas reforzaría uno de los lemas de propaganda asociados al desarrollismo español de aquellos años: España al doble. "Es frase - aseveraba Fraga- que no puede quedarse en simple 'slogan', que ha de ser una espléndida realidad" 47 . El nuevo proyecto musical se concebía, por tanto, como resultado del crecimiento español y de la idea aceptada en el equipo del MIT de que el desarrollo económico debía englobar igualmente un desarrollo cultural y artístico: “En esa España, señores, y en ese próximo 'Objetivo 67' con que se ha trazado una meta el Plan de Desarrollo Económico y Social, el serio conjunto instrumental que creamos ahora es una pieza con la que progresan y se enriquecen también nuestros elementos artísticos" ${ }^{48}$.

\section{Consolidación del proyecto}

Las gestiones para la creación de la nueva orquesta se sucedieron con relativa rapidez. Apenas un mes más tarde de la publicación en el Boletín Oficial del Estado de la Orden por la que se autorizaba la creación del conjunto sinfónico, se convocó el concurso-oposición para cubrir las ochenta y tres plazas de los profesores que habían de integrarlo ${ }^{49}$. Las pruebas, a las que se presentaron hasta trescientos músicos, comenzaron el 16 de noviembre de 1964 y se extendieron a lo largo del mes siguiente ${ }^{50}$. Para todos los seleccionados, las condiciones contractuales con el Ministerio incluían una jornada laboral de siete horas diarias y un día de descanso a la semana, así como "plena dedicación", siendo incompatible la pertenencia a la orquesta

46 "La Orquesta Nacional de España, dependiente del Ministerio de Educación Nacional, seguirá prestando su brillante colaboración ante las pantallas de la Televisión. Deseamos también que las demás orquestas sinfónicas españolas sigan siendo las amigas insustituibles que nutran con su arte interpretativo los cauces de las necesidades, cada vez más crecientes, de nuestra acción en pro de la cultura popular". La cita en "Palabras del Excmo. Sr. Ministro de Información y Turismo, Don Manuel Fraga Iribarne, en el acto de toma de posesión de los profesores de la Orquesta Sinfónica de la Radio-Televisión Española, leídas el 25 de enero de 1965", AGA, Fondo (3), 49.12, Legajo: 44201, Sig. Top. 32/72. Para "subrayar la armonía" existente entre los dos Ministerios, Fraga propuso al ministro de Educación asistir de forma conjunta al acto de toma de posesión de los profesores de la nueva orquesta. Carta de Manuel Fraga a Manuel Lora Tamayo, 19-I-1965, AGA, Fondo (3) 49.09, Legajo: 38674, Sig. Top. 23/54.

47 "Palabras del Excmo. Sr. Ministro de Información y Turismo...", p. 4.

48 Ibid.

${ }^{49}$ BOE,${ }^{\circ}{ }^{173,20-V I I-1964 . ~ U n ~ n u ́ m e r o ~ q u e ~ s e ~ i n c r e m e n t o ́ ~ e n ~} 1965$ hasta los noventa músicos.

${ }^{50}$ El jurado estaba presidido por Óscar Esplá y contaba con la presencia del director del Conservatorio de Madrid, Cristóbal Halffter; el jefe de Programas Musicales de Radio Nacional, Enrique Franco; el catedrático de Piano del Conservatorio madrileño, Pedro Lerma -en representación de la Dirección de Información-; y el compositor Federico Contreras -en representación de Televisión Española-, "Orquesta de Radiodifusión y TV", Tele-Radio, n. ${ }^{\circ} 357$, 1964, p. 59. 
con cualquier actividad en otros conjuntos musicales ${ }^{51}$. A cambio, se les dotaba de una "merecida consideración económica". Se trataba, en fin, de condiciones que no eran muy comunes en el resto de orquestas españolas de la época, donde los profesores estaban acostumbrados a coleccionar trabajos para poder vivir con cierta holgura ${ }^{52}$.

Tras la selección de los profesores faltaba por determinar la composición de la Junta Rectora, organismo llamado a ostentar la responsabilidad directa en todos los asuntos relacionados con el nuevo conjunto sinfónico ${ }^{53}$. Así, la Junta estaría encargada de redactar su reglamento, confeccionar y aprobar el plan de programación artística, proponer el presupuesto económico anual, planificar la contratación de personal y adoptar "toda clase de acuerdos sobre el régimen y buen gobierno de la Orquesta". Sus miembros fueron finalmente designados en noviembre de 196454: ostentaría la presidencia el director general de Radiodifusión, Jesús Aparicio-Bernal, y la vicepresidencia el subdirector general de Cultura Popular, Enrique de la Hoz. Los vocales de la Junta eran los subdirectores de Radio y Televisión, Manuel Aznar y Luis Ezcurra, respectivamente; el director musical de la orquesta - cargo que todavía estaba vacante-; el jefe de Programas Musicales de RNE, Enrique Franco, y su asesor musical, Antonio Ramírez-Ángel ${ }^{55}$; el jefe de programas musicales de TVE, José María Fernández Quero ${ }^{56}$, y su asesor musical, Fernando Díaz-Giles ${ }^{57}$; el jefe de la Sección de Campañas y Festivales, Joaquín Araujo Dualde; y, en calidad de secretario, el catedrático de Piano del Conservatorio Superior de Madrid, Pedro Lerma ${ }^{58}$. El

51 "Reglamento de la Orquesta de la Radio y Televisión Española...".

52 Según Fraga, los salarios de los profesores de la OSRTVE eran símbolo de la elevación social que en adelante había de experimentar el músico y que lo situaba merecidamente "al nivel de los más distinguidos puestos que sirven los nobles intereses del Estado": "A tono con la catalogación social y humana que merecen quienes justamente son llamados profesores -porque un músico, señores, no es sólo un artista, es también un intelectual-, estos han de responder en su cuota de rendimiento con una alta cifra de perfección y calidad". "Palabras del Excmo. Sr. Ministro de Información y Turismo...", p. 2.

53 Robles Piquer comunicó al director general de Radiodifusión que, si no se establecía con prontitud este órgano de trabajo, podría quedarse al margen de la elección de profesores y entrar en conflicto con las decisiones que tomara el jurado ya convocado. Carta de Robles Piquer a Jesús Aparicio-Bernal, 23-XI-1964, AGA, Fondo (3) 49.09, Legajo: 38669, Sig. Top. 23/54.

${ }^{54}$ BOE, n. ${ }^{\circ} 287,30-X I-1964$.

55 Ramírez-Ángel era, según Enrique Franco "una de las cabezas visibles de la generación musical de 1916, acaso la más sufrida profesionalmente a consecuencia de la Guerra çcivil". E. Franco: "Antonio Ramírez-Ángel, un músico de Madrid", El País, 29-IV-1986. Trabajó en el conservatorio madrileño y fue secretario de la revista Música, publicada entre 1952 y 1954 bajo la dirección de Federico Sopeña. Parte de su obra estuvo destinada a la música cinematográfica.

56 Anteriormente había trabajado como jefe de programas musicales de la Cadena SER y más tarde llegaría a ser un reconocido realizador de televisión.

${ }^{57}$ Hijo del célebre compositor de zarzuelas del mismo nombre, Fernando Díaz Giles. Fue el responsable del Servicio de Montaje Musical de TVE, desde donde se creaban sintonías para los programas de televisión y se seleccionaba la música para la carta de ajuste.

${ }^{58}$ El secretario de la Junta era también, según el "Reglamento de la Orquesta de la Radio y Televisión Española...", secretario de la Orquesta. Una vez que Pedro Lerma fue nombrado director del "Club 
administrador de la Orquesta sería Benjamín Arbeteta, periodista y escritor que desarrollaba parte de su trabajo en Televisión Española ${ }^{59}$.

Quedaban en el aire dos últimos asuntos que demandaban una solución urgente. Por un lado, la domiciliación de la Orquesta, cuestión no menor por la escasa oferta de espacios adecuados y que, finalmente, quedó fijada en el auditorio del MIT ${ }^{60}$. Por otro, el nombramiento de los directores, que dado el volumen y variedad de actividades encomendadas al conjunto sinfónico debían ser, al menos, dos o tres. Más espinoso resultó el procedimiento de selección. Los responsables de la OSRTVE recibieron presiones desde el principio, por lo que se decidió establecer un sistema "tan objetivo como sea posible [...] a fin de no responsabilizar de una cuestión, que al fin y al cabo es técnica, al ministro o a sus colaboradores inmediatos" 61 . Para evitar el nombramiento directo, en el MIT se manejó una fórmula que debía ser la "más honesta, más libre y eficaz entre las conocidas" 62 . No era otra que la del concurso-oposición, tal y como reconocía Robles Piquer: "Entre otras cosas porque eliminaría automáticamente a ciertos candidatos que no desearán someterse a dicho concurso y que, sin embargo, son capaces de movilizar influencias políticas para conseguir sus deseos"63.

En última instancia se apostó por un sistema mixto. Primero se nombró de forma directa al director titular, quien debía ser un maestro de reconocida fama internacional y ostentaría el puesto durante el período de tiempo

de Conciertos de Festivales de España”, en octubre de 1965, se nombró secretario a Alfonso García Aijón. Este último crearía más adelante, en 1970, la asociación de conciertos Ibermúsica.

${ }^{59}$ La Junta descartó la presencia de Joaquín Rodrigo (el compositor fungía como asesor musical de RNE, un cargo honorífico que no tenía cometido concreto, pero sí sueldo mensual) y de Cristóbal Halffter, y en su lugar optó por Ramírez-Ángel y Díaz-Giles, ambos funcionarios de la Dirección General de Radiodifusión, que contaban con un perfil más técnico. "Notas sobre el nombramiento como integrantes de la Junta Rectora de la Orquesta Sinfónica de la Radio Televisión Española a un asesor musical de la Radio Nacional de España y a un asesor musical de Televisión", AGA, Fondo (3) 49.09, Legajo: 38674, Sig. Top. 23/54

60 Tras algunas dudas al respecto -se pensó en el Teatro de la Zarzuela, la sede de TVE en Prado del Rey o el futuro Palacio de Exposiciones y Congresos-, se eligió finalmente el auditorio ubicado en la cuarta planta del Ministerio de Información y Turismo, inaugurado en 1962. Esta sala se encontraba en el n. ${ }^{\circ} 39$ de la Avenida del Generalísimo -hoy Paseo de la Castellana n. ${ }^{\circ} 109$, sede del Ministerio de Defensa-. Además de contar con espacio suficiente para la instalación de oficinas para la Secretaría de la Orquesta y el almacenamiento del material musical y archivístico, ofrecía la clara ventaja de albergar en el mismo edificio la sala de conciertos y los estudios de RTVE. Otros asuntos menores, como la adquisición de partituras, se resolvieron gracias a la ayuda de las Orquestas Sinfónica y Filarmónica de Madrid, las cuales ofrecieron su archivo a cambio de no ver mermada su participación en los Festivales de España. "Acta correspondiente a la reunión de la Junta Rectora de la Orquesta de RTV Española", 17. II-1965. AGA, Fondo (3) 49.12, Legajo: 44201, Sig. Top. 32/72.

${ }^{61}$ El Ministerio se reservaba, "naturalmente", el derecho de veto "por motivos políticos si el caso se presentara". Carta de Carlos Robles Piquer a Jesús Aparicio-Bernal, 23-XII-1964, AGA, Fondo (3) 49.09, Legajo: 38669, Sig. Top. 23/54.

62 "La Orquesta Sinfónica de la RTV Española", enero-diciembre 1965, p. 8. AGA, Fondo (3) 49.09, Legajo: 38674, Sig. Top. 23/54.

${ }_{63}$ Carta de Robles Piquer a Aparicio-Bernal, 23-XII-1964. 
"necesario para la formación técnica y estética del conjunto". A continuación se convocó un concurso-oposición para cubrir dos plazas de codirectores de entre las figuras musicales españolas más destacadas ${ }^{64}$. Un proceso que se calificó de singular por su nivel europeo, su carácter justo y objetivo, y lo novedoso de su puesta en práctica en España ${ }^{65}$.

Antes de designar al director titular se hizo una encuesta entre las personas más destacadas del medio musical español, quienes mostraron su predilección por el director de origen ucraniano Igor Markevitch ${ }^{66}$. No obstante, tras establecer los contactos oportunos, la Agencia Daniel ${ }^{67}$-que controlaba la agenda del músico- informó de que no podría hacerse cargo de la dirección de la OSRTVE hasta enero de $1966^{68}$. Se encargó entonces a Enrique Franco que sondeara a Mario Rossi, director de la Orquesta Sinfónica de la RAI, a Igor Stravinsky e incluso a Sergiu Celibidache para que asumieran el cargo hasta la incorporación de Markevitch ${ }^{69}$. Mientras tanto, la Orquesta comenzó los ensayos a las órdenes de José María Franco Bordons y Cristóbal Halffter, quienes emprendieron la "labor de ensamblaje y concertación del conjunto"70. In extremis, Markevitch aceptó regir la OSRTVE en su debut ${ }^{71}$, aunque todavía sin confirmar si le sería posible aceptar la futura dirección debido a sus múltiples compromisos ${ }^{72}$.

${ }^{64}$ Los directores adjuntos ocuparían el puesto durante un período de dos años, prorrogable hasta un máximo de diez, "Resolución de la Dirección General de Radiodifusión y Televisión por la que se convoca concurso-oposición para proveer dos plazas de directores de la Orquesta de la Radio y Televisión Española", BOE, n. ${ }^{\circ}$ 75, 29-III-1965.

${ }^{65}$ La iniciativa se había consultado previamente con críticos musicales, directores de Conservatorio y presidentes de distintas asociaciones. "La Orquesta Sinfónica de la RTV Española...".

66 "La música en el Ministerio de Información y Turismo. Boletín Informativo", octubre 1965, AGA, Fondo (3) 49.09, Legajo: 38674, Sig. Top. 23/54. Algunos años más tarde, y a raíz de ciertas discrepancias en materia musical entre Cristóbal Halffter e Igor Markevitch, aquel reconocería que él mismo había propuesto a Markevitch como director de la orquesta de RTVE: "El señor ministro y otros altos cargos de ese Ministerio aceptaron como excelente mi idea y se pusieron en marcha para hacer las gestiones que culminaron en el resultado que todos conocemos". Sin embargo, y pese a no arrepentirse de su iniciativa, Halffter manifestaba que habían surgido "hondas diferencias" entre "su idea y su realización". En concreto, se lamentaba de la escasa protección y atención al compositor español y su obra, de lo que hacía responsable a los directores de las dos orquestas nacionales (Igor Markevitch y Rafael Frühbeck) por no programar suficiente música española contemporánea. Cristóbal Halffter: "Situación crítica del compositor en España...", p. 23.

${ }^{67}$ Fundada en 1914 por Ernesto Quesada, esta agencia se encargó de traer a España a los más reconocidos directores y músicos internacionales. Como ha señalado Alfonso García Aijón, Ernesto Quesada fue "el padre de todos, el de la Agencia Vitoria, de Felicitas Keller, y el mío". Entrevista realizada por Daniel Verdú: "El padrino de la clásica en España", El País, 22-XII-2012.

68 "Acta correspondiente a la reunión de la Junta Rectora de la Orquesta de RTV Española...", 17-II-1965.

69 "Acta correspondiente a la reunión de la Junta Rectora de la Orquesta de RTV Española...", 24II-1965.

70 "La Orquesta Sinfónica de la RTV Española...", p. 3.

71 "Finalmente tuvimos la fortuna de contratar un primer director realmente extraordinario, el exiliado Igor Markevitch, a quien solíamos llamar el príncipe Igor, porque lo parecía", Carlos Robles Piquer: Memoria de cuatro Españas..., p. 187.

72 "Markevitch. Director invitado de la Orquesta Sinfónica de la Radio y Televisión Española", Ritmo, n. ${ }^{\circ} 352$, abril 1965, p. 9. La presentación oficial del director no se produjo hasta octubre de 1965. Con 
Por su parte, el jurado del concurso-oposición para la elección de los directores adjuntos estuvo formado por Ernesto Halffter, Enrique Jordá, Joaquín Zamacois, Xavier Montsalvatge, Francisco Calés y Pedro Lerma, que actuó como secretario ${ }^{73}$. Quedaron cuatro opositores finalistas para las dos plazas vacantes:Vicente Spiteri, Pedro Pírfano, Enrique García Asensio y Antoni Ros-Marbà. La elección final recayó en favor de estos dos últimos debido, según el jurado, al reconocimiento internacional que ya poseían y a su trayectoria en la vida musical española. Además, ambos directores, que contaban 28 años, "polarizaban las simpatías del mundo musical joven de España"74. De este modo, la designación de los codirectores se correspondía plenamente con los propósitos de la nueva Orquesta, que había surgido, entre otras razones, para dar mayor protagonismo a las últimas generaciones de compositores ${ }^{75}$.

Constituida la Junta Rectora y nombrada su dirección, la nueva Orquesta de Radio y Televisión se disponía a iniciar su andadura mostrando "un estilo nuevo en la forma y en el fondo", a través de "la plena y exclusiva dedicación de sus componentes", de "la racional ordenación del trabajo y la severa disciplina", y de "la integración social de un núcleo de artistas al servicio de un estamento cultural" 76 .

\section{Debut y primeros conciertos}

La presentación oficial de la Orquesta de Radiotelevisión Española tuvo lugar en el Teatro de la Zarzuela, durante el II Festival de Ópera de Madrid, el 27 de mayo de 1965, con un concierto exclusivo de carácter sinfónico. No obstante, la primera vez que la orquesta hizo su aparición "en la vida pública" y adquirió "carta oficial de naturaleza"77 fue una semana antes, el 20 de mayo, en el concierto inaugural del Festival Internacional de Música Contemporánea $^{78}$, bajo la dirección de Odón Alonso.Y ello porque los

ella, Markevitch se incorporó a la actividad normal de la Orquesta y a su Junta Rectora. El director ruso, que sería reconocido como "director fundador" de la orquesta, permaneció en el puesto hasta marzo de 1969 y luego quedó como director honorario. Antonio Fernández-Cid: "Igor Markevitch en nueva situación con la RTVE", ABC, 21-III-1969, p. 81.

73 José Ramón Ripoll: Cuarenta años sonando. La Orquesta Sinfónica de RTVE..., p. 16.

74 "La Orquesta Sinfónica de la RTV Española...", p. 9.

${ }^{75}$ A Igor Markevitch no le agradó la idea de compartir "podio y batuta" con dos directores más y, según cuenta Enrique García Asensio, se encargó de dejar claro en alguna ocasión que eran "ayudantes". Al parecer esta actitud tenía que ver también con cierta rivalidad profesional de Markevitch con el que fuera maestro de García Asensio y Ros-Marbà, el director rumano Sergiu Celibidache. José Ramón Ripoll: Cuarenta años sonando. La Orquesta Sinfónica de RTVE..., pp. 18-19.

76 "La Orquesta Sinfónica de la RTV Española...", p. 9.

77 "Boletín Programa 1. XXXIX Festival Mundial Sociedad Internacional Música Contemporánea", 20-V-1965, AGA, Fondo (3) 49.09, Legajo: 38679, Sig. Top. 23/54.

${ }^{78}$ Este Festival había sido organizado por la Sección Española de la Sociedad Internacional de Música Contemporánea (SIMC) y celebrado en Madrid entre el 20 y el 28 de mayo de 1965. España no 
responsables de la Orquesta habían acordado con la Sección Española de la SIMC que aquella se hiciese cargo de dos de los cuatro conciertos previstos para el Festival ${ }^{79}$. La Junta Rectora, consciente de la mayor resonancia que lograría la OSRTVE si asumía un programa compuesto en su totalidad por música española ${ }^{80}$-evitando las obras extranjeras y contemporáneas-, trató de presionar al presidente de la Sección Española de la SIMC, Óscar Esplá. Este no tardó en responder mediante una carta en la que mostraba su disgusto ante las imposiciones de la Junta: "En todos los países donde se celebran los festivales anuales de nuestra Sociedad Internacional, las orquestas se ofrecen a lo que disponga el Comité Nacional de la SIMC, organizador del festival, a quien incumbe exclusivamente toda decisión de orden técnico y estético"81.

Además, apuntaba Esplá, los programas se habían establecido "teniendo en cuenta lo que cada intérprete puede hacer mejor", ya que más importante que el éxito de la orquesta era el éxito de las obras interpretadas:" $\mathrm{La}$ orquesta de la Radio y TV española actuará en dos conciertos que contienen obras de autores del máximo prestigio mundial, y podrá mostrar así sus cualidades que son las de una orquesta joven muy estimable, pero todavía sin madurez, que no se logra de buenas a primeras, aunque la Junta Rectora de la Orquesta se crea otra cosa" 82 .

Al final se interpretaron obras contemporáneas y, como era previsible, la reacción de público y crítica fue bastante fría. El programa, por su carácter vanguardista, "no se prestaba demasiado a apreciar su calidad y sus recursos" $"$. De hecho, en la segunda participación de la orquesta en el Festival,

había albergado la celebración de un Festival de la SIMC desde 1936, edición que tuvo lugar en Barcelona, poco antes del inicio de la Guerra Civil. De ahí la amplia repercusión que este evento tuvo en el ambiente musical del momento.

79 "Acta correspondiente a la reunión de la Junta Rectora de la Orquesta de RTV Española...", 24II-1965. Debido a las dificultades de Markevitch para compatibilizar estos conciertos con sus compromisos internacionales, se decidió que Odón Alonso, por entonces director de la Filarmónica de Madrid, llevase la batuta en las dos ocasiones.

${ }^{80}$ Era costumbre en todas las ediciones de la SIMC reservar un concierto a la música del país anfitrión.

${ }^{81}$ Carta de Óscar Esplá a Enrique de la Hoz, 10-II-1965, AGA, Fondo (3) 49.09, Legajo: 38679, Sig. Top. 23/54.

82 Ibid. En otra carta, de 9-II-1965, dirigida a Antonio Iglesias, Esplá apuntaba hacia esta misma idea, señalando que la OSRTVE carecía de un director titular que pudiese empezar a ensayar con tiempo y le faltaba "hábito de conjunto": "Es absolutamente indispensable mostrar a los Delegados Nacionales de las Secciones de la SIMC lo que la música española ha producido de máximo prestigio, en las mejores condiciones de interpretación", AGA, Fondo (3) 49.09, Legajo: 38679, Sig. Top. 23/54. Finalmente, del concierto exclusivo de música española se hizo cargo la Orquesta Nacional.

83 Ángel del Campo: "Primer concierto sinfónico con la Orquesta de RTVE", Pueblo, 24-V-1965, p. 39. El programa fue el siguiente: Stasimon B! (1964) de Yorgo Sicilianos, Concerto pour piano et orchestre (1964) de Yoritsuné Matsudaira, Spiegel II (1961) de Friedrich Cerha y Deuxième Symphonie (1959) de André Jolivet. 
el 28 de mayo, acudió poco público al teatro ${ }^{84}$. En cualquier caso, la dificultad de las obras, muchas de ellas interpretadas en primera audición, revelaba "la capacidad de trabajo y auténtica eficacia" de la nueva Orquesta ${ }^{85}$.

Contrasta esta tibia recepción con el entusiasmo que siguió a la presentación oficial de la Orquesta, el 27 de mayo, ya de la mano de Markevitch. Entonces se habló de actuación "apoteósica" y "triunfal”, con un programa que, esta vez sí, había facilitado un aplauso sin fisuras ${ }^{86}$. En definitiva, una "jornada histórica" 87 que no dudó en vincularse al "período conmemorativo de los 25 Años de Paz" 88 y que significaba "más que un día de triunfo, la iniciación de una nueva etapa en el vivir musical español"89.

Ante el éxito logrado, con "ovaciones interminables" y "lleno completo" -"todo el Madrid social, cultural, artístico y político estaba en el Teatro de la Zarzuela" $90-$, se decidió repetir el concierto pocos días después en el Monumental Cinema con un triunfo "aún mayor, aún más cálido si cabe, que el día de la presentación" 91 . Tal y como estaba programado, el 8 de junio la OSRTVE hizo su presentación en Barcelona con un programa ligeramente distinto ${ }^{92}$. La iniciativa del Ministerio de Información y Turismo de llevar la Orquesta a la ciudad condal fue "acogida con un gran interés en los medios barceloneses" ${ }^{93}$, si bien, en un primer momento, el Liceo

\footnotetext{
${ }^{84}$ Antonio Fernández-Cid: "XXXIX Festival Mundial de la SIMC: Tercer concierto sinfónico", Informaciones, 29-V-1965, p. 14. En esta ocasión se interpretó Szene II (1961) de Bo Nilsson, Epitaffio per orchestra É nastro magnético (1963) de Arne Nordheim, Freski symfoniczne (1964) de Kazimierz Serocki, Symphonie op. 21 (1928) de Anton Webern, Abraham and Isaac (1963) de Igor Stravinski, y Survivor from Warsaw (1947) de Arnold Schoenberg.

${ }^{85}$ Fernando Ruiz Coca: "El festival de la SIMC y Ópera en Madrid”, La Estafeta Literaria, n. ${ }^{\circ} 220$ 221, 19-VI-1965, p. 76. No sabemos con certeza si estos conciertos fueron retransmitidos por televisión ya que, según se indicaba, "carecen de interés" para este medio por su "inevitable minoritarismo". En cambio, RNE sí grabó la mayoría de los conciertos del Festival de la SIMC para distribuirlos a las cadenas internacionales y, en especial, a los países miembros de dicha organización. "Asuntos Festival Mundial SIMC", AGA, Fondo (3) 49.09, Legajo: 38679, Sig. Top. 23/54.

${ }^{86} \mathrm{El}$ concierto se celebró en el Teatro de la Zarzuela con arreglo al siguiente programa: la Sinfonía Clásica, de Prokofiev; el Preludio de Tristán e Isolda, de Wagner; el Sombrero de tres picos, de Falla; y la Quinta Sinfonía, de Beethoven. Como preámbulo, y como solía ser habitual en este tipo de actos, se interpretó el himno nacional, en esta ocasión con orquestación de Cristóbal Halffter. El concierto fue retransmitido en directo por RNE y en diferido por TVE. En 1982, y coincidiendo con el último concierto que daría con la OSRTVE, Markevitch se despidió dirigiendo el mismo programa, esta vez en el Teatro Real. José Ramón Ripoll: Cuarenta años sonando. La Orquesta Sinfónica de RTVE..., p. 27.

${ }^{87}$ Antonio Fernández-Cid: "Triunfal concierto de presentación de la Orquesta de la RTV Española", Informaciones, 28-V-1965, p. 9.

88 “300 para 83", Ritmo, n. ${ }^{\circ} 348,1-X I-1964$, p. 3.

89 "España, Festival de cultura", Arriba, 30-V-1965, p. 2.

90 Enrique Franco: "Sensacional presentación de la Orquesta Sinfónica de RTV Española, dirigida por Markevitch", Arriba, 28-V-1965, p. 20. Al concierto asistió el ministro de Información y Turismo, con el equipo político y técnico que había hecho posible la creación del conjunto.

${ }^{91}$ Manuel Carra: "Triunfa de nuevo la Orquesta Sinfónica de RTV Española", Arriba, 1-VI-1965, p. 31.

92 En esta ocasión se interpretó la Obertura de La Cenerentola, de Rossini; el Preludio de Tristán e Isolda, de Wagner; el Sombrero de tres picos, de Falla; y la Primera sinfonía, de Brahms.

93 Xavier Motsalvatge: "Presentación de la Orquesta de la RTV Española", La Vanguardia, 3-VI-1965.
} 
recibió al conjunto con "una buena disposición no exenta de frialdad"94. A pesar de los recelos iniciales, el público catalán acabó demostrando un "entusiasmo" que "se desbordó de manera inenarrable" 95.

Tras los conciertos de debut, se anunció la participación de la Orquesta en los programados dentro de la temporada de Festivales de España, lo que llevaría al conjunto por un buen número de ciudades. Se conseguía así, como señalaba Enrique de la Hoz, que "la nuestra no sea una orquesta sedentaria [...], pues está creada para tres vehículos extremadamente móviles: la Radio Nacional, a la cual busca el melómano; la Televisión, a la que no es necesario buscar, pues ella sola se coloca diariamente ante diez millones de españoles; y los Festivales, que no son otra cosa que una especie de gran carro de la farándula que recorre el país" ${ }^{\prime}$.

La OSRTVE participó, entre junio y septiembre de 1965, en doce Festivales de España, sumando un total de dieciocho conciertos, incluido el concierto-homenaje a Ataúlfo Argenta celebrado en Castro Urdiales ${ }^{97}$. Siguiendo los propósitos iniciales, la Orquesta daba cumplida cobertura a los eventos sinfónicos de las distintas localidades españolas. Sin embargo, los conciertos del nuevo conjunto solo se programaron en las grandes ciudades, aquellas que contaban con un presupuesto más elevado y podían afrontar los elevados honorarios de la Orquesta, que ascendían a 160000 pesetas por actuación ${ }^{98}$. Esta cantidad superaba las posibilidades económicas de la mayoría de Ayuntamientos y Diputaciones Provinciales, que se vieron imposibilitados para contratar sus servicios:"Es cierto que esta situación ha de producir cierta desilusión, precisamente entre los que podemos denominar peor dotados, pero se comprende también que no existe posibilidad de actuar distintamente" 99 .

94 "Declaraciones del Subdirector de Cultura Popular", ABC, 20-VI-1965, p. 65. En esta entrevista, Enrique de la Hoz daba a entender el carácter poco complaciente del público barcelonés, que pese a todo se había rendido ante la calidad de la Orquesta.

95 "La gran ovación de Barcelona a la Orquesta Sinfónica de la RTV Española", La Vanguardia, 10VI-1965, p. 33.

96 "Declaraciones del Subdirector de Cultura Popular...", p. 65.

${ }^{97}$ En este concierto, celebrado el 22 de agosto en la localidad santanderina, De la Hoz pronunció un discurso en memoria de Ataúlfo Argenta. Argenta no solo había sido una de las personas más destacadas "en la historia musical de la España en Paz de los últimos 25 años", sino también el pionero en ocupar el cargo de dirección del primer conjunto sinfónico de RNE, en los años cuarenta. Unos años, según palabras de De la Hoz, marcados por la "miseria en que por entonces quería sumirnos el mundo, hostil e incomprensivo para con un país que quería renacer a toda costa". "Palabras del subdirector general de Cultura Popular en el homenaje a la memoria de Ataúlfo Argenta...", p. 4, AGA, Fondo (3) 49.12, Legajo: 44201, Sig. Top. 32/72.

98 Esta cantidad era muy superior a las 75000 pesetas por concierto que percibían los pequeños conjuntos orquestales, compuestos por medio centenar de músicos, que solían hacerse cargo de estas representaciones. Igualmente era una cantidad menor a las 275000 pesetas que pedía la ONE por cada concierto.

99 "Informe del jefe de la Sección de Campañas y Festivales a la Junta Rectora de la Orquesta de RTV Española”, AGA, Fondo (3) 49.12, Legajo: 44201, Sig. Top. 32/72. 
Aunque Markevitch era el director titular de la Orquesta, los primeros conciertos estuvieron a cargo de hasta seis directores más, cinco españoles y uno extranjero ${ }^{100}$. De esta forma, el MIT pudo saldar ciertos compromisos contraídos con directores como José María Franco y Cristóbal Halffter, quienes durante los primeros meses de vida de la OSRTVE ejercieron de "directores-entrenadores" a cambio de "participar como directores invitados en varios conciertos tan pronto la Orquesta tuviese vida pública"101. Por su parte, Ernesto Halffter dirigió tres conciertos en Madrid,Vigo y Altea, con un solo programa. Su colaboración respondía a "una vieja promesa del Ministerio de Información y Turismo" finalmente cumplida ante los deseos retiradamente manifestados por el compositor. A Enrique de la Hoz, sin embargo, no terminaba de agradarle esta "dirección rotatoria" a que fue sometida la OSRTVE: en una carta remitida al presidente de la Junta Rectora, Jesús Aparicio-Bernal, subrayaba la necesidad de "cuidar al máximo la presencia pública de la Orquesta y evitar extremadamente los trances de "compromiso"'.Y ello por el mal papel desempeñado por Ernesto Halffter durante el concierto ofrecido el 22 de julio en el Retiro:

La minoría que protestó al final con algún “¡Fuera!” y “AA estudiar al Conservatorio!" se produjo con clara intención contra el director, no muy afortunado en las versiones de las obras por él mismo seleccionadas. Todos sabemos que el nombre ilustre que dirigió incidentalmente no es director profesional, sino un gran compositor que, como otros muchos, dirige a veces. No podríamos hacer una defensa a ultranza de él derivando culpabilidades a la Orquesta, ni siquiera al recinto, ni tampoco a la organización de Festivales ${ }^{102}$.

De la Hoz reconocía que estos "meneos" se producían de cuando en cuando en los conciertos públicos. Para evitarlo, el próximo que había de celebrarse en Madrid se organizaría "con todas las garantías", en un local cerrado, aunque las "gamberradas", según el subdirector de Cultura Popular, "pueden producirse siempre en nuestro medio [...] con Jordá, con Markevitch y con el mismísimo Toscanini que resucitara. Somos así"103.

\footnotetext{
${ }^{100}$ José María Franco, Cristóbal y Ernesto Halffter, Odón Alonso, Enrique Jordá y el belga André Vandernoot.

${ }^{101}$ A José María Franco le correspondió el primer concierto dado en Sevilla y a Cristóbal Halffter el segundo, más otros dos en Mérida y Burgos. "Informe del subdirector general de Cultura Popular y Comisario General de 'Festivales de España' sobre la gira de la Orquesta Sinfónica de la RTV Española en 'Festivales de España' 1965”, 13-IX-1965, p. 2, AGA, Fondo (3) 49.09, Legajo: 38674, Sig. Top. 23/54.

102 De la Hoz aseguraba que, según cierta información "de imposible comprobación, pero muy verosímil", los "reventadores" -como él los llamaba- pertenecían al grupo de opositores descalificados por el tribunal del que Ernesto Halffter había sido presidente. Carta de Enrique de la Hoz a Jesús Aparicio-Bernal, 31-VII-1965, AGA, Fondo (3) 49.09, Legajo: 38674, Sig. Top. 23/54.

${ }_{103}$ Ibid.
} 
Mejor recibimiento tuvieron los conciertos ofrecidos por Odón Alonso en Santiago de Compostela, Santander y Castro Urdiales; y por Enrique Jordá en La Coruña, Bilbao y Madrid. Los de este último significaron, probablemente, "los más resonantes éxitos de esta etapa veraniega"104. Los conciertos ofrecidos por Igor Markevitch en Santander, Cuenca y San Sebastián gozaron "del éxito y la brillantez que siempre es garantía tras el nombre de Markevitch". Por último, la Orquesta contó con un maestro internacional invitado, André Vandernoot, quien dirigió en Santander un concierto "gris y para cumplir, nada más" 105 .

Así pues, la OSRTVE desplegó una intensa actividad, con el montaje de once programas distintos a lo largo de catorce semanas, una cifra sin duda ambiciosa para los primeros meses de vida de un conjunto. En este sentido, Enrique de la Hoz consideraba injustos los comentarios aparecidos en determinados periódicos, que hablaban de "los demasiados conciertos" ofrecidos por la Orquesta, y hacía alusión directa a $A B C$ y al responsable de su sección musical, Federico Sopeña, a quien calificaba de "enfant terrible de la crítica"106:

Tal crítico se suele invalidar a sí mismo cuando incurre en frecuentes contradicciones. Se sabe, por otra parte, que en sus artículos siempre tiene que estar inconforme con algo. En esta ocasión, dentro de la mesura y el respeto con que ha tratado a la Orquesta (y con elogiosos artículos a la labor de extensión musical de los Festivales de España) tuvo que decir y tratar de justificar lo de demasiados conciertos y, veladamente, también que demasiados y poco buenos directores ${ }^{107}$.

El artículo a que hacía referencia De la Hoz fue publicado el 20 de agosto de 1965; en él, el crítico musical hablaba precisamente del concierto celebrado en Santander y dirigido porVandernoot: "Es muy de alabar esa prisa del Ministerio de Información por hacer viajera a su orquesta; sin embargo, tratándose de una orquesta tan joven, tan en período de formación, todavía sin directores fijos, hubiera sido mejor ejercer una cierta cautela, una cierta paciencia, limitándose a pocos y bien preparados conciertos y en batutas muy escogidas" 108 .

104 "Se trata [Odón Alonso] de uno de los pocos, contadísimos, directores de orquesta españoles que dirigen por el mundo, con nombre bien acreditado y éxito popular [...]. Cabe recordar el gran éxito en el Monumental Cinema de Madrid, lleno de público. [...] ¡Piénsese que era el 4 de agosto!”. La cita proviene del "Informe del subdirector general de Cultura Popular...", p. 3.

105 Esta actuación vino "impuesta" por la Agencia Victoria para acompañar a la soprano Elisabeth Schwarzkopf. Haberla rechazado habría significado reducir la presencia de la Orquesta en el evento y un agravio comparativo con la ONE, que acaparó cuatro de los siete conciertos ofrecidos en el Festival de Santander, Ibid.

106 Enrique de la Hoz comentaba que Sopeña aplicaba "rigurosamente aquel refrán sudamericano que dice así: "palo porque bogas, palo porque no bogas”, Ibid., p. 8.

Ibid. Los subrayados aparecen en el documento original.

108 Federico Sopeña: "Vandernoot, con la orquesta de la RTV", ABC, 20-VIII-1965, p. 57. "Ni Mozart, ni un pasajero concierto de Vandernoot sirven para una orquesta en ese estado inicial. Incluso para un futuro próximo me parece mucho un concierto semanal antes de que esa orquesta lo sea de verdad". 
Al crítico no le faltaba una parte de razón: como el propio De la Hoz reconocería, la primera etapa de la vida de la Orquesta se había visto sometida a una carga excesiva, dadas las obligaciones propias del conjunto y recogidas en su reglamento interno: "No es la nuestra, tampoco, una orquesta de señoritos" 109 .

A las anteriores apreciaciones de Sopeña se sumaban los comentarios de otros críticos que calificaban a la OSRTVE de bisoña y señalaban el "defecto de su juventud". Unas críticas que, según el subdirector de Cultura Popular, no tenían ninguna intención constructiva:

A veces suelen esconder la labor de zapa del adversario -que los hay, los hayfastidiado por los triunfos y el material de buena ley con que todo esto, vivo y fehaciente, está montado.Y cuando no hay mala intención en los calificativos, sí hay ingenuidad, tópico, plagio de otros cuando el comentarista es incapaz de pensar y apreciar por sí mismo.Y puros sofismos para quedar bien ${ }^{110}$.

Más allá de estas críticas, la mayoría de los comentarios aparecidos en prensa alababa la calidad de la Orquesta. Incluso la agencia británica Reuters hizo circular en medios internacionales una noticia favorable sobre la creación del conjunto sinfónico del MIT. Los miembros de la Junta Rectora se felicitaron por este excepcional hecho, pues las agencias foráneas solían enviar normalmente información "poco halagadora para España, y a veces no verídica" 111 .

Una de las señas de identidad de la OSRTVE debía ser la especial atención al repertorio de música española actual. Pero esto no había ocurrido, al menos con la intensidad deseada, en la campaña de Festivales de 1965. Una escasez que fue señalada por "la crítica, los medios musicales y aún el vox populi"112. Quizá el que más se destacó subrayando esta carencia fue, como de costumbre, Federico Sopeña: "Del Festival de Santander necesitamos señalar y criticar la ausencia de música española y la

\footnotetext{
109 "Informe del subdirector general de Cultura Popular...", p. 8.

110 Ibid., p. 9.

111 "España cuenta con una joven y dinámica Orquesta Sinfónica de nueva creación, de la cual esperamos muchas cosas los críticos musicales [...]. La edad media de los 86 componentes de la Orquesta es de 30 años. En mis 25 años de música, no había oído nunca a una Orquesta de nueva creación desarrollar o interpretar un programa con tanta calidad [...]". Transcripción de la noticia de Reuters en una nota interna de Enrique de la Hoz a los miembros de la Orquesta Sinfónica de la RTV Española, 5VI-1965, AGA, Fondo (3) 49.09, Legajo: 38674, Sig. Top. 23/54. La noticia apareció posteriormente en la prensa española. En este sentido, la creación de la orquesta animó a algunos directores internacionales a ofrecerse como directores invitados en futuros conciertos, como el austríaco Fritz Mahler, Howard Mitchel (director titular de la Orquesta Sinfónica Nacional de Washington), Herrera de la Fuente (director de la Orquesta Nacional de México), o el ruso -y norteamericano de adopción-, André Kostelanetz. "Notas del subdirector general de Cultura Popular, Enrique de la Hoz, al secretario técnico de la Orquesta de la Radio y TVE, Pedro Lerma", AGA, Fondo (3) 49.09, Legajo: 38674, Sig. Top. $23 / 54$.

112 "Memorando del vicepresidente de la Junta Rectora de la Orquesta Sinfónica de la RTV Española para la reunión del 11-X-1965”, p. 3, AGA, Fondo (3) 49.09, Legajo: 38674, Sig. Top. 23/54.
} 
escasa representación de los grandes solistas españoles en los conciertos sinfónicos"113.

Se incumplía así el propósito manifestado ante la prensa por Enrique de la Hoz, quien aseguraba que cada programa de la Orquesta incluiría "una obra española, sobre todo de música actual"114. Sin embargo, en un documento interno del Ministerio, el subdirector de Cultura Popular y vicepresidente de la Junta Rectora de la OSRTVE insistía en el compromiso que el conjunto sinfónico habría de tener con la música española:"La Orquesta está creada -entre otras funciones- para ser vivero y caldo de cultivo de la música española. La tradicional y la de creación actual deberá tener frecuente, reiterada e indispensable presencia en los programas regulares de la misma" 115.

Parecida postergación sufrió la música de vanguardia, que había tenido poco peso en los programas de verano de 1965, con independencia de los conciertos ofrecidos durante el Festival de Música Contemporánea de la SIMC en el mes de mayo. No era ningún secreto que la promoción de esta música chocaba con el escepticismo de las autoridades, del público e incluso de parte de la crítica. Aun así, Enrique de la Hoz reiteraba la necesidad de promocionar la música contemporánea, una tarea que calificaba de "misión cultural":

Por encima de gustos personales, o de las legítimas "resistencias" a la expansión musical de nuestro tiempo, constituye una obligación estética, una insoslayable necesidad cultural, dar a conocer la música actual y las corrientes que la informan, si queremos mantener una tónica artística a nivel europeo y universal. La participación de este tipo de música entre experimental y renovadora es también una obligación informativa, tanto si se está con ella como contra ella ${ }^{116}$.

De manera que para consolidar esta apertura los programas de la OSRTVE debían prestar un interés destacado a las obras de compositores claves del movimiento musical contemporáneo, aun "con todas las dosificaciones y precauciones necesarias"117. Así, la música española había de estar encabezada por "el Director del Conservatorio de Madrid, Cristóbal Halffter, y De Pablo o Bernaola”. Esta innovación estratégica aseguraría

113 Federico Sopeña: "Los festivales y el festival de Santander", ABC, 4-IX-1965, p. 57. De las dieciséis obras de compositores españoles interpretadas por la OSRTVE a lo largo de 1965, solo tres pertenecían a la joven generación, y todas ellas eran del mismo compositor, Cristóbal Halffter: Secuencias, Dos movimientos para timbal y orquesta y Concierto para piano y orquesta. "Anexo II. Obras interpretadas por la Orquesta Sinfónica de la RTV Española en 1965”, AGA, Fondo (3) 49.09, Legajo: 38674, Sig. Top. 23/54.

114 "La Orquesta ha de ser, lo será, un cauce permanente para el entusiasmo y el talento de los compositores españoles". "Declaraciones del subdirector de Cultura Popular", ABC, 20-VI-1965, p. 66.

115 "Memorando del vicepresidente de la Junta Rectora...", p. 3.

116 Como señalaba Enrique de la Hoz, de haber cerrado "nuestras puertas a este movimiento musical", la música española se habría mantenido en el mismo punto los últimos 25 años. Ibid., p. 4.

${ }^{117}$ Los compositores "claves" eran Karlheinz Stockhausen, Pierre Schaeffer, Arnold Schoenberg, Olivier Messiaen, Anton Webern, Alban Berg, Pierre Boulez, Luigi Nono y Hans Werner Henze, entre otros. 
cierta popularidad entre "la gran masa de gente joven, [...] que será seguidora de nuestro programa de acción cultural musical si se equilibra éste con acierto" 118 .

Lo que sí se logró fue que la radio y la televisión recogiesen los primeros conciertos de la Orquesta ofrecidos en los Festivales de España. RNE grabó la mayoría de ellos, trece en total; se exceptuó, entre otros, el de Santander, por las "dificultades establecidas por la Agencia Victoria", derivadas de la actuación de Elisabeth Schwarzkopf ${ }^{119}$. TVE, por su parte, estuvo presente en solo cuatro conciertos: Santiago de Compostela, Santander, Bilbao y Madrid -esta última transmisión frustrada por "averías técnicas del equipo"-120.

Con todo, la Orquesta Sinfónica de Radiotelevisión Española había comenzado a cumplir la misión para la que fue creada: "enriquecer verdaderamente la vida musical española" y "sembrar la inquietud por la música en muchos lugares" a través de los Festivales de España y su actividad en radio y televisión. Enrique de la Hoz confiaba en que la orquesta significase un antes y después en la operación socio-cultural del Ministerio y que la música sinfónica se situase a la "altura estética con que se lleva el teatro, la danza y la pintura" 121.1966 llegaba preñado de nuevos proyectos: se pensaba crear una especie de Club de Música en Madrid para fomentar la asistencia de los aficionados a los conciertos de la OSRTVE en el auditorio del Ministerio, atrayendo así a un público formado por estudiantes del Conservatorio, del SEU y de los Colegios Mayores y por socios de diversas asociaciones musicales. En último término, quedaba pendiente la creación de un coro adscrito a la orquesta, así como una programación específica para radio y televisión con la que se completara la labor del nuevo conjunto ${ }^{122}$.

\footnotetext{
118 Ibid.

119 Desconocemos cuándo se retransmitieron dichos conciertos, pero sí sabemos que pudieron escucharse a través de Radio Nacional de Buenos Aires y la cadena de radiodifusión marroquí Rabat. AGA, Fondo (3) 49.09, Legajo: 38674, Sig. Top. 23/54.

120 "Informe del subdirector general de Cultura Popular...". Las retransmisiones televisivas de estos conciertos aún presentaban ciertas deficiencias que no ayudaban, precisamente, a la "popularización" de estos programas. Con motivo de una de esas emisiones -el concierto de la OSRTVE de Bilbao, el 21 de agosto-, en el mes de octubre, se señalaba este hecho: "La forzosa monotonía de imagen con un señor hablando ofrece el peligro de aburrir hasta producir, incluso, el apagar el receptor por el televidente, sobre todo por aquel público no directamente interesado en un concierto 'culto' -que suma mayoría-, al que se debe 'captar' y estimar como presunto 'futuro aficionado"'. "Observaciones al concierto de la Orquesta Sinfónica de la RTV Española del domingo 3 de octubre de 1965 en TVE”, AGA, Fondo (3) 49.09, Legajo: 38674, Sig. Top. 23/54. Para ofrecer una imagen más atractiva se proponía la utilización de una voz "en off" y evitar poner anuncios con música después del concierto, ya que, "por una serie de circunstancias técnicas", el sonido del anuncio era de mejor calidad que el de la retransmisión, lo que dejaba en evidencia a esta última. Ibid.

121 "Informe del subdirector general de Cultura Popular..."

122 "Puntos de vista sobre las necesidades de la Orquesta Sinfónica de la RTV Española a partir del mes de octubre de 1965", 13-XII-1965, AGA, Fondo (3) 49.09, Legajo: 38674, Sig. Top. 23/54.
} 


\section{Coda}

La creación de la Orquesta de la Radiotelevisión Española dio un impulso decisivo a la vida sinfónica española de los años sesenta. El establecimiento de una temporada de conciertos, la fijación de una audiencia cada vez más numerosa en el Auditorio del MIT y posteriormente en el Palacio de la Música y el Teatro Real, o la programación musical impulsada desde Radiotelevisión Española -gracias, sobre todo, a la aparición de las emisiones en frecuencia modulada con un alto contenido musical de Radio 2, conocida posteriormente como Radio Clásica- reforzaron el papel del nuevo conjunto. Una consolidación que no puede entenderse sin el apadrinamiento oficial que la acompañó. Si la política musical del MIT entre 1962 y 1965 trató de acaparar y organizar la máxima variedad de actos, tras la creación de la OSRTVE sus esfuerzos en se centraron, principalmente, en la organización de los Festivales de España y la gestión exclusiva del nuevo conjunto sinfónico.

Tanto Fraga como sus más cercanos colaboradores estaban convencidos de que la orquesta contribuiría a la modernización en el plano cultural que por entonces ambicionaba el régimen. Además, desde un punto de vista político, el MIT pensaba despertar elevadas dosis de "popularidad" y "simpatía” entre aquellos sectores de población más ilustrados y, por ello, generalmente más críticos con la dictadura, los cuales verían con mejores ojos un Gobierno preocupado por las artes y la música, a la manera de las democracias occidentales. La OSRTVE significó, por tanto, una pieza fundamental dentro de la vasta política de imagen del franquismo implementada por el MIT en la década de 1960, dirigida a situar la cultura como uno de los ejes principales sobre los que construir la España del desarrollo. 